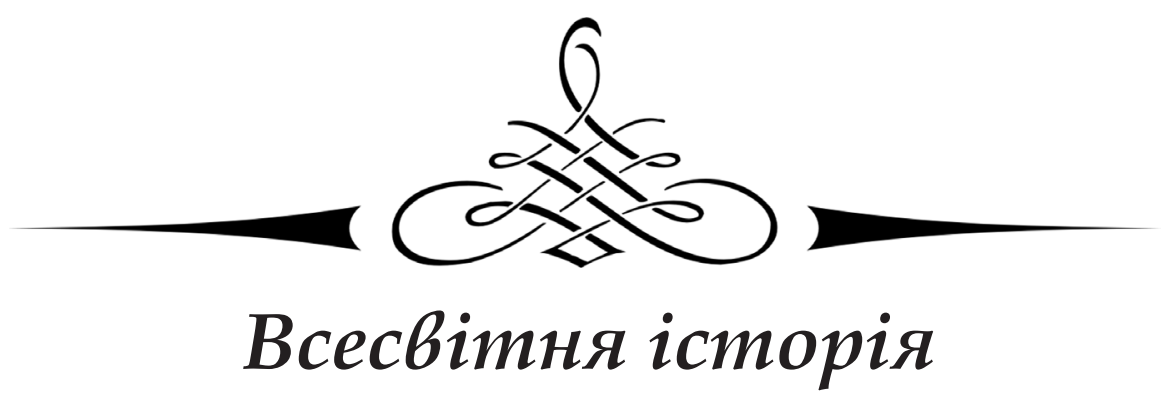

UDC 929.731(410):7.041:070:004.77

DOI https://doi.org/10.26661/zhv-2020-3-55-19

\title{
THE ROYAL FAMILY IMAGE IN THE BRITISH MEDIA
}

\author{
0. M. Maklyuk \\ Zaporizhzhia National University \\ onmacluk@gmail.com \\ ORCID: https://orcid.org/0000-0002-8740-2402
}

\author{
V. V. Volkova \\ Zaporizhzhia National University \\ valeriavol2578@gmail.com \\ ORCID: https://orcid.org/0000-0001-5802-7095
}

\section{A. M. Manuylova \\ Zaporizhzhia National University \\ AnnaManuylova01@gmail.com \\ ORCID: https://orcid.org/0000-0001-7983-5710}

Key words: mass media, the Royal Family, Great Britain, Elizabeth II, the institution of monarchy, the press, image, media person, Internet resources, social networks.
The article examines the role of the UK media in shaping the image of the Royal Family of Windsor. It is suggested that permanent «availability» of information about the Royal Family in the media is evidence of purposeful, systematic work on its image. The public perception of the Royal Family image created by the media is analysed, and the attitude of the British towards the monarch's family is elucidated. In the framework of scientific research, the main sources for analysis of the Royal Family as media personalities are materials from periodicals, radio/television and Internet resources. Instagram Facebook, Twitter and other social networks efficiently used by the Royal Family are in the special focus of this article. It is concluded that with the help of modern media, the Royal Court and the life of the Royal Family is again gaining relevance: not only does this communication channel ensure that the society is provided with information, it also enables receiving feedback. Until the mid-twentieth century, the members of the Royal Family had tried to maintain privacy and mete out the information presented to the public. The situation changed with the beginning of the reign of Queen Elizabeth II, which gave rise to new traditions, levelled the information gap between the monarch and his subjects, made the Royal Family closer to society.

It is determined that the conservative, monarchical traditions shaped in British society over the centuries continue to influence the formation of the British people's positive attitude towards the Royal Family. However, today the image of the Royal Family is approaching people: it has acquired the blurred borders in terms of preserving aristocracy. Despite the changes, the priority of the Royal Family in shaping its own image lies in the cult of restraint and simplicity, which creates an attractive idea of monarchy as an institution. For the British people, the Royal Family is primarily the embodiment of monarchy, image of the state, which is why the control of information for the media is not only a family matter, but a state matter, which can potentially affect the image of the monarchy, both inside the country and abroad. 


\title{
ОБРАЗ КОРОЛІВСЬКОЇ РОДИНИ У БРИТАНСЬКИХ ЗМІ
}

\author{
О. М. Маклюк, В. В. Волкова, А.М. Мануйлова \\ Запорізький національний університет
}

Ключові слова: засоби масової інформації (3МI), королівська родина, Велика Британія, Єлизавета II, інститут монархії, преса, образ, імідж, медіа-персона, Інтернет-ресурси, соціальні мережі.

у роботі досліджено роль засобів масової інформації Великої Британії щодо формування образу королівської родини Віндзорів. Проведено аналіз сприйняття суспільством образу створеного 3МІ. З'ясовано ставлення громадян країни до королівської родини та інституту монархії у цілому. Визначено, що сформовані у британському суспільстві століттями консервативні, монархічні традиції продовжують впливати на формування позитивного ставлення британців до королівської родини. Королівська родина сьогодні для британців, це передусім втілення монархії, образу держави, саме тому контроль за інформацією, що потрапляє у 3 MI стає не просто родинною справою, а справою державною, що потенційно впливає на образ монархії, як в країні, так і поза її межами.

Presentation of the problem. Over five recent decades, with the development of technology, the mass media influence on society has been growing exponentially, thus making relevant the scientific research related to the study of this phenomenon. It should be emphasized that nowadays the innovative means of communication and information transmission - the Internet - has complemented the traditional radio, television and print media. Mass communication has acquired more significance in shaping modern public thought, and the latest models of communication and information transmission have changed the nature of relations between the media and the public. Mass media has always been an important factor in transmission, preservation and popularization of the existing socio-political myths as a form of historical memory fixation, a component of mass consciousness that contributes to formation of behavioural paradigms and modelling concepts of socio-political reality.

In the modern media space, political myths related to activities of monarchies and royal families are extremely popular. The depiction of the image of the monarchy as a political institution in the mass media has drawn our attention. In addition, the relevance of studying this issue is reinforced by the fact, which is emphasized by Olena Sherman, Doctor of Political Science, an expert in the technologies of mass media impact on the political process, who states that logically, this topic should be marginal in the Ukrainian media space, however, the phenomenon observed is the contrary ${ }^{1}$.

Currently, monarchies exist in more than 40

\footnotetext{
1 Шерман 0. М. Засади висвітлення інституту монархї у сучасних 3MI. URL:http://virt.ldubgd.edu.ua/pluginfile. php/14209/mod_folder/content/0/кафедра\%20С\%20та\%20 ГД/Шерман\%200.M/Sherman_5.pdf?forcedownload=1
}

countries, including 13 European countries, namely: Sweden, Norway, Denmark, Spain, Belgium, the Netherlands, Andorra, Liechtenstein, Monaco and others. However, there is no doubt that the most famous of modern monarchies is the British Royal Family. According to a survey published in the Guardian, as of 2000 , only $44 \%$ of the respondents believed that the situation in the UK would deteriorate dramatically without the monarchy, and this was the lowest indicator of the Royal Family popularity in recent decades. Back in the early 1990s, the British monarchy was supported by $70 \%$ of the country's population. As far as the respondents' age is concerned, Queen Elizabeth II and her family are supported by the older generation. Approximately $40 \%$ of the respondents aged from 18 to 24 spoke out against the monarchy or were completely indifferent to this issue ${ }^{2}$.

Despite the heated discussions of the second half of the $20^{\text {th }}$ - early $21^{\text {st }}$ century about the expediency of the monarchy existence, the UK citizens have preserved this institution as a symbol of their country, structure that unites society and strengthens the international relations of the state. In turn, modern monarchies, despite the fact that they are the embodiment of tradition and conservatism, are also adapting and adjusting to new conditions. By using the means of information industry, they violate the established traditions and stereotypes that have been shaped for centuries, and present a new format of relations with society, demonstrating openness. In our opinion, permanent "availability" of information about the Royal Family in the media is evidence of purposeful, systematic work on the Family image and,

Support for royal family falls to new low. The Guardian. 12.07.2000URL: https://www.theguardian.com/uk/2000/ jun/12/monarchy.alantravis/ (Last accessed: 01.04.2019). 
consequently, institution of monarchy as a whole.

Review of the related up-to-date academic literature. Currently, the research dedicated to shaping public opinion on the Royal Family and institution of monarchy in the British media is represented in the scientific sources by single publications. We should note the contribution to the research of the given topic made by representatives of both domestic and foreign scientific schools, namely J. Hartley ${ }^{3}$, A. Tan ${ }^{4}, 0$. Sherman ${ }^{5}$ and others. However, in modern socio-humanitarian studies there is a lack of professional systemic research of the given problem, which opens up numerous research horizons.

In this context, the purpose of our study is to analyse the image of the Royal Family of Windsor created by the British media and to determine the impact of information content on shaping of the public opinion about the Royal Family and monarchy as a whole.

Results and discussion. Talking about coverage of a topic or event in the media, we should pay attention to the fact that the audience perceives a created image of the actual phenomenon rather than the phenomenon as it is. In this paper, "image" is understood as a subjective category, which exists in the minds of people. "Image" is inseparable from the phenomenon, but never fully possesses its properties. However, the situation may be the contrary: a set of features, characteristics and qualities fixed in the mind can replace this phenomenon. It is also important to note that having appeared once, the "image" acquires an active guiding role in human behaviour ${ }^{6}$.

Public people, whose lives and activities have been and are being covered in the media, are in the focus of public attention. In this regard, it is natural to talk about media players who serve as permanent newsmakers. The very mention of such persons' names ensures success of the media content with the audience. However, among news-

\footnotetext{
Hartley John. Communication, cultural and media studies. The Key Concepts. London, 2002. URL: http:// Library.uniteddiversity.coop/Media_and_Free_Culture/ Communication_Culture_and_Media_Studies-John_Hartley. pdf (Last accessed: 07.01.2019).

${ }^{4}$ Tan A. Mass communication theories and research. London. URL: https://www.academia.edu/5570981/Mass_media_discourse_A_ critical_anal ysis_research_agenda/(Last accessed: 07.01.2019).

5 Шерман 0. М. Засади висвітлення інституту монархії у сучасних 3MI. URL:http://virt.ldubgd.edu.ua/pluginfile. php/14209/mod_folder/content/0/кафедра\%20С\%20та\%20 ГД/Шерман\%200.M/Sherman_5.pdf?forcedownload=1

6 Философская энциклопедия. Акалемик. URL: http://dic. academic.ru/dic.nsf/enc_philosophy/4605/\%D0\%9E\%D0\%91 \%D0\%A0\%D0\%90\%D0\%97 (дата звернення: 03.01.2019)
}

makers mentioned, there are people who make the media vigilant due to private life circumstances or active social activities. This vigilance creates a unique media story, which, in turn, not only causes constant excitement of the public, but also, being attached to these newsmakers, shapes their image, in fact - their second biography. The object of such constant attention, both inside and outside the United Kingdom, is the Royal Family. The royalty attract attention not only as an aristocratic clan, or celebrity that has gained popularity due to frequent mentioning in the yellow press, glossy magazines and gossip columns, but as a national symbol of the United Kingdom, which for many years has been the embodiment of the state's image, showing restraint and conservatism, preserving tradition and isolation.

In this article, the main sources for analysing the Royal Family's image formation are materials from periodicals, radio/television, Internet resources provided to the public in various formats - from official documents and statements to news feeds, interviews of the Royal Family members, memoirs, official biographies, speeches transcripts, official pages in social networks, etc. In the current environment, social networks are an effective platform for social and communication practices, which have become a channel of information and communication for the Royal Family as well. This is the reason why social media, namely Facebook, Twitter and Instagram, are of special attention within the framework of our scientific search.

Despite constant attention, the relations of the ruling Royal dynasty with the media have always been considerate; the members of the monarch's family tried to maintain privacy: they meted out information to the public and restricted communication channels. With the beginning of the reign of Queen Elizabeth II, the situation changed, which gave rise to new traditions.

Radio and television developed at a faster pace and took the lead among mass media in the middle of the $20^{\text {th }}$ century. Talking about radio or TV in the UK, the first company to mention is the BBC (The British Broadcasting Corporation) ${ }^{7}$. Of course, the lives of the Royal Family members were covered in their releases. In 1952, the BBC - then the sole broadcaster in the UK - addressed the Palace for permission to broadcast the coronation ceremony of Queen Elizabeth II. Against the advice of the then Prime Minister Winston Churchill and the

\footnotetext{
7 The British Broadcasting Corporation URL: https://www.bbc. com/ (Last accessed: 26.10.2019).
} 
Church, who believed that inviting cameras (and the public) to watch the ceremony would "desecrate the sacred event", Elizabeth insisted that the event be broadcast on television. The coronation ceremony was the first Royal event to be broadcast live. It was a defining moment in the development of the British broadcasting; millions of Britons watched the event at home. Queen Elizabeth II insistence on the presence of cameras in Westminster Abbey signalled a desire to be in the spotlight and demonstrated the understanding of the fact that the Royal Family's position depends on public support. In addition, television coverage of the coronation event can be seen as a targeted strategy: for the first time in history, the gap between the public and the secrecy of the Royal Court has disappeared.

Shaping of the Royal family's positive image in society is closely linked with the name of Princess Diana, who brought the Family closer to society through active charity activities, which certainly had a positive impact on the image of the Royal Family. It is Diana's charities that gained the highest popularity and recognition for her. After the divorce, she focused on social activities and helping people, which she reported in her interviews ${ }^{8}$. Princess Diana continued to act as a patron of the Centrepoint organization (engaged in providing accommodation and support to young people), Leprosy Mission (a global Christian organisation, whose mission is medical care and improvement of life quality of patients with leprosy), National Aids Trust (a Foundation, which provides support to people living with HIV) as well as the head of several other organizations engaged in providing assistance to hospitals and clinics 9 .

Princess Diana was engaged in the Campaign to Ban Landmines: she called for a ban on anti-personnel devices, which caused severe injuries to the civilian population of former British colonies. The Princess joined this campaign a year before her death. In winter of 1997, she went to Angola, and in the summer, she attended the conference of the Royal Geographical Society in London, where they discussed the use of weapons. Then she made a visit to the United States of America, which was to promote the Red Cross landmine campaign. In

\footnotetext{
8 Стенограмма интервью леди Дианы для программы ВВС «Панорама». [Текст стенограммы беседы] URL: http://soro. narod.ru/Articles/bbc.htm/ (дата звернення: 23.02.2019).

9 The house of Windsor from 1952. Diana, Princess of Wales. Public role URL:http://www.royal.gov.uk/ HistoryoftheMonarchy/The $\% 20$ House $\% 20$ of $\% 2$ Windsor $\% 20$ from\%201952/DianaPrincessofWales/PublicRole.aspx/ (Last accessed: 23.02.2019).
}

addition, Diana also visited Bosnia and some other countries where the tragedy caused by anti-personnel mines was some of the greatest ${ }^{10}$.

Princess Diana's humanitarian mission in Angola was covered in the documentary created by the $\mathrm{BBC}$ on her initiative. The film includes all the video footage shot in Africa as well as an interview with the Princess. In the interview, Diana told about her personal impressions of meeting the people who were crippled by mines and also voiced threatening statistics: 1 person out of 333 civilians lost a limb, and all this happened in the country with poor quality of medical care and ongoing local conflicts ${ }^{11}$. In this documentary, there are words that the Princess emphasized on: her actions are designed to attract the attention of the world community and have nothing to do with politics ${ }^{12}$. During this period, Diana gained the image of a humanitarian person. Using the media power and speed of information dissemination, Diana drew attention to sensitive and extremely important humanitarian issues.

The situation for the British media changed dramatically after the tragic death of Princess Diana. "People accepted that what happened to Diana was wrong and, as a consequence, new notions of privacy which had been historically alien to us were applied," said Mark Stephens, a media law specialist with the firm Howard Kennedy ${ }^{13}$. There were no personal privacy laws before Diana's death, except in areas such as medicine, religion, a marital bed, and death. The Protection from Harassment Act (PHA) was only introduced in 1997, but after the fatal car accident (August 1997) ${ }^{14}$. From January 1998, the use of photos from the private life of any person

10 The house of Windsor from 1952. Diana, Princess of Wales. Public role URL:http://www.royal.gov.uk/ HistoryoftheMonarchy/The $\% 20$ House $\% 20$ of $\% 20$ Windsor $\% 20$ from\%201952/DianaPrincessofWales/PublicRole.aspx) (Last accessed: 23.02.2019).

11 How princess Diana crippled the case for land mines. Newsweek special edition. 24.10.2015. URL: http://europe. newsweek.com/princess-diana-diana-william-harry-princewilliam-prince-harry-royal-family-335391?rm=eu/ (Last accessed: 22.02.2019).

12 How princess Diana crippled the case for land mines. Newsweek special edition. 24.10.2015. URL: http://europe. newsweek.com/princess-diana-diana-william-harry-princewilliam-prince-harry-royal-family-335391?rm=eu/ (Last accessed: 22.02.2019).

${ }^{13}$ The Princess and the Paparazzi: How Diana's Death Changed the British Media URL: http://time.com/4914324/princessdiana-anniversary-paparazzi-tabloid-media/ (Last accessed: 29.10.2019).

${ }^{14}$ The Protection from Harassment Act (PHA) URL: http://www. justice.gov.za/legislation/acts/2011-017.pdf/ (Last accessed: 22.02.2019). 
without his consent was deemed "unacceptable." 15

The death of Princess Diana significantly affected the actions of the media in the UK and around the world. However, there are still cases when paparazzi behave dangerously, trying to make piquant and provocative pictures to attract more audience. The terrible and shocking tragedy forced journalists to reconsider their attitude to interference into private life.

Today, the image of the Royal Family is getting closer to the people, acquiring blurred borders in terms of preserving the aristocracy. The new members of the Royal Family (Kate Middleton, Meghan Markle) have certainly attracted the attention of both the media and the world. Usually, wives for monarchs were chosen based on their origin. They must be of noble birth, from a well-to-do and problem-free family. However, neither Kate nor Meghan had an aristocratic background. The images of the two duchesses are very different in the minds of British citizens. Reading the press, you might think that the lives of the two women are like a sports competition for being the priority of the press and British people.

With the birth of children in the family of Kate and William, the British people's commitment to the monarchy began to grow again. This family embodies the ideal image of a family. Despite their status, Kate and William pay much attention to their children and their development. Under the curatorship of the Duchess of Cambridge, the Chelsea Wildlife Garden opened. With her example, Kate shows that being outside and enjoying nature has a positive impact on physical and mental health, in particular on children's development ${ }^{16}$. Meghan and Harry's having a baby has a significant affect. Archie Harrison Mountbatten-Windsor has not only the British roots, but American and African-American. Due to this fact, he has a chance to go down in history as the most unusual heir.

In the $21^{\text {st }}$ century, the situation has changed: not only the mass media, but also the members of the Royal Family have mastered the new channels and are shaping their own image. They cover their activities, using an opportunity to present themselves in the best way possible, to suppress or flaunt some issues. In this context, the pages of the Royal

\footnotetext{
${ }^{15}$ The Princess and the Paparazzi: How Diana's Death Changed the British Media URL: http://time.com/4914324/princessdiana-anniversary-paparazzi-tabloid-media/ (Last accessed: 29.10.2019).

${ }^{16}$ Post of Kensington Palace. Twitter. 20.05.2019 URL: https:// twitter.com/KensingtonRoyal/status/1130337604925366272 (Last accessed: 22.05.2019).
}

Family members on social networks are representative. Facebook is the largest social network in the world. On February 8, 2010, the page of the Members of the Royal Family of Windsor was officially created $^{17}$. This page is not personal, but corporate. The page was created by the young members of the Royal Family. It contains videos, photos and news not only about Queen Elizabeth II, but also about other members of the Royal Family. Their official Facebook page also provides the Court Circular - a schedule of receptions, visits, audiences and other engagements of the Royal Court. As of June 2020, approximately 5,153,728 people are following the life of the Windsor Family via Facebook ${ }^{18}$ (which shows a significant increase in the interest - in January 2019 , there were $4,879,800$ people, meaning an increase makes up 273,928 subscribers). Their official Twitter ${ }^{19}$ and Instagram ${ }^{20}$ accounts are accessible via the links on the Facebook page. It is important to note that the pages provide information of a neutral nature. In our opinion, the creation of these pages enables the Royal Family to get closer to people, which is important for preserving the integrity of the nation. In addition to the official pages, there are many "fan pages"; however, among them there are some providing negative comments on the Royal Family. Of course, all the information on the Internet affects the shaping of the public opinion about the Royal Family.

On Instagram alone, there are more than a dozen of official pages related to the Royal Family. The first is @theroyalfamily ${ }^{21}$,which is where we can see photos and videos about work and activities of Queen Elizabeth II and the Royal Family. The following pages cover the lives of married couples, namely Charles, the Prince of Wales and Camilla, the Duchess of Cornwall (@clarencehouse)22, Prince William, the Duke of Cambridge and Kate, the Duch-

\footnotetext{
17 The Royal Family. Facebook URL: https://www.facebook. com/TheBritishMonarchy/ (Last accessed: 07.01.2019).

18 The Royal Family. Facebook URL: https://www.facebook. com/TheBritishMonarchy/ (Last accessed: 07.01.2019).

19 The Royal Family. Twitter URL: https://twitter.com/ RoyalFamily/ (Last accessed: 29.10.2019).

20 The Royal Family. Photos and videos about the work \& activities of The Queen \& the Royal Family. Instagram URL: https://www.instagram.com/theroyalfamily/ (Last accessed: 29.10.2019).

${ }^{21}$ The Royal Family. Photos and videos about the work \& activities of The Queen \& the Royal Family. Instagram URL: https://www.instagram.com/theroyalfamily/ (Last accessed: 29.10.2019).

22 Clarence House. Photos and videos from Clarence House about the life, work and activities of The Prince of Wales and The Duchess of Cornwall. Instagram URL: https://www. instagram.com/clarencehouse/ (Last accessed: 07.01.2019).
} 
ess of Cambridge (@kensingtonroyal) 23. Recently, the page of Prince Harry, the Duke of Sussex and Meghan, the Duchess of Sussex (@sussexroyal) ${ }^{24}$ has been created.

Below, we will trace the dynamics of the Internet pages' development. The page of the Royal Family@theroyalfamily was created on March 26, 2013, as proved by its first post. As of mid-2020, the activities of the Royal Court and Elizabeth II were officially viewed by 8 million people $(1.2$ million more than in 2019). There are only 1.1 million subscribers to the page of Prince Charles and Camila (as of 6 May, 2018). In other words, the interest in this page is considerably lower, but we can also see an increase compared to the previous year. Before the events of March 30,2020, (the resignation of the Dukes of Sussex), the official pages of William and Kate (11.8 million followers) and of Harry and Meghan (11 million followers) competed. They gained such popularity within a very short time. This showed that the younger generation of the Royal Family was more active in gaining popularity with users of social networks. With the help of modern media, the Royal Court and the life of the Royal Family are again gaining relevance: not only they inform people about ceremonial events; they also can get feedback, contact people and see their attitude to certain events in the life of the country and the Royal Family.

A significant event in the history of the British people and the world was the post on the Instagram page of the Duke and Duchess of Sussex on January 8,2020 , in which they announced their intention to "step back" as senior members of the Royal Family, become financially independent and balance their time between the UK and the US. This statement made such a fuss, as Meghan and Harry had informed not only their subscribers and newsmakers, but also their relatives in this "newest way in history". Neither the Queen, nor the father and even the brother were aware of such intentions. It was a heavy blow to the integrity of the family. This news was commented on in all the media, including social networks. Jonny Dymond, a BBC correspondent, wrote on Twitter, "Buckingham Palace was "blindsided"... Prince Harry and Meghan did

\footnotetext{
${ }^{23}$ Kensington Palace. The official account of The Duke and Duchess of Cambridge, based at Kensington Palace. Instagram URL: https://www.instagram.com/kensingtonroyal/ (Last accessed: 26.10.2019)

24 The Duke and Duchess of Sussex. The official Instagram account of The Duke and Duchess of Sussex. Instagram. URL: https://www.instagram.com/sussexroyal/ (Last accessed: 01.11.2019).
}

not consult any royal about making their personal statement" ${ }^{\prime 25}$. On March 30,2020, with the last post on the official Instagram page of Meghan and Harry (@sussexroyal) ${ }^{26}$, a new page was turned not only in their personal lives - a new "era" of the British monarchy started.

From the above, we can make the conclusion that Buckingham Palace is making great efforts to modernize the monarchy in the $21^{\text {st }}$ century. However, the conservative monarchical traditions, which have been formed in the British society for centuries, surely continue to influence the shaping of Britons' positive attitude to the Royal Family. The Queen remains the real ideal, a role model for the current and future generations of the British people who are proud to be her subjects. It was with the beginning of the reign of Elizabeth II that the information gap between the monarch and her subjects began to disappear, the Queen and the Royal family got closer to society, which became a priority for the ruling dynasty. Queen Elizabeth II confidently demonstrates historical conservatism: no scandalous cases, interviews, she is devoted to British traditions. Perhaps, this is the reason for her popularity with the common people. The Royal Family cultivates restraint and simplicity, embodies an attractive and confident image of the UK for the world.

Having analysed newspapers, Internet resources, video resources and social networks, we can conclude that in the public mind of the British society as a whole, a predominantly positive image of the Royal Family and institution of monarchy is shaped through various channels of mass communication. Today, the Royal Family is primarily the embodiment of the monarchy, the image of the state, which is why the control of information for the media and use of new means of the Royal Family self-presentation, cases of Diana and Harry are not just family matters - they can potentially destroy a positive image of the monarchy, both inside the country and abroad.

Research prospects: the research problem has not been considered in full; there are significant prospects for further scientific analysis. The results of this research paper can be used as a premise for comparative research of shaping public opinion on the institution of monarchy in Europe.

\footnotetext{
25 Jonny Dymond. Twitter URL: https://twitter.com/Jonny Dymond/status/1215013510066905091/ / (Last accessed: 09.01.2020).

${ }^{26}$ The Duke and Duchess of Sussex. The official Instagram account of The Duke and Duchess of Sussex. Instagram. URL: https://www.instagram.com/sussexroyal/ (Last accessed: 01.11.2019).
} 


\section{References}

Stenogramma interv'yu ledi Diany dlya programmy BBC «Panorama». [Tekst stenogrammy besedy] URL: http://soro. narod.ru/Articles/bbc.htm/ (data zvernennya: 23.02.2019).

Filosofskaya enciklopediya. Akademik. URL: http://dic.academic.ru/dic.nsf/enc_philosophy/4605/\%D0\%9E\%D0\% 91\%D0\%A0\%D0\%90\%D0\%97 (data zvernennya: 03.01.2019).

Sherman 0. M. Zasadi visvitlennya institutu monarhiï u suchasnih ZMI. URL:http://virt.ldubgd.edu.ua/pluginfile. php/14209/mod_folder/content/0/kafedra\%20S\%20ta\%20GD/SHerman\%200.M/Sherman_5.pdf?forcedownload=1

Clarence House. Photos and videos from Clarence House about the life, work and activities of The Prince of Wales and The Duchess of Cornwall. Instagram URL: https://www.instagram.com/clarencehouse/ (Last accessed: 07.01.2019).

How princess Diana crippled the case for land mines. Newsweek special edition. 24.10.2015. URL: http://europe. newsweek.com/princess-diana-diana-william-harry-prince-william-prince-harry-royal-family-335391? rm=eu/ (Last accessed: 22.02.2019).

Jonny Dymond. Twitter URL: https://twitter.com/JonnyDymond/status/1215013510066905091/ / (Last accessed: 09.01.2020).

Kensington Palace. The official account of The Duke and Duchess of Cambridge, based at Kensington Palace. Instagram URL: https://www.instagram.com/kensingtonroyal/ (Last accessed: 26.10.2019).

Post of Kensington Palace. Twitter. 20.05.2019 URL: https://twitter.com/KensingtonRoyal/status/ 1130337604925366272 (Last accessed: 22.05.2019).

Support for royal family falls to new low. The Guardian. 12.07.2000URL: https://www.theguardian.com/uk/2000/ jun/12/monarchy.alantravis/ (Last accessed: 01.04.2019).

The British Broadcasting Corporation URL: https://www.bbc.com/ (Last accessed: 26.10.2019).

The Duke and Duchess of Sussex. The official Instagram account of The Duke and Duchess of Sussex. Instagram. URL: https://www.instagram.com/sussexroyal/ (Last accessed: 01.11.2019).

The house of Windsor from 1952. Diana, Princess of Wales. Public role URL:http://www.royal.gov.uk/HistoryoftheMonarchy/The\%20House\%20of\%20Windsor\%20from\%201952/DianaPrincessofWales/PublicRole.aspx/ (Last accessed: 23.02.2019).

The Princess and the Paparazzi: How Diana's Death Changed the British Media URL: http://time.com/4914324/princess-diana-anniversary-paparazzi-tabloid-media/ (Last accessed: 29.10.2019).

The Protection from Harassment Act (PHA) URL: http://www.justice.gov.za/legislation/acts/2011-017.pdf/ (Last accessed: 22.02.2019).

The Royal Family. Facebook URL: https://www.facebook.com/TheBritishMonarchy/ (Last accessed: 07.01.2019).

The Royal Family. Photos and videos about the work \& activities of The Queen \& the Royal Family. Instagram URL: https://www.instagram.com/theroyalfamily/ (Last accessed: 29.10.2019).

The Royal Family. Twitter URL: https://twitter.com/RoyalFamily/ (Last accessed: 29.10.2019). 